\title{
REPRESENTAÇÕES DO BRASIL NAS BROCHURAS TURÍSTICAS LUSO- INGLESAS: PRÓXIMAS DO PARAÍSO E DISTANTES DA CIVILIZAÇÃO
}

\author{
Representations of Brazil in Portuguese-English tourist brochures: close to paradise and far from civilization \\ Representaciones de Brasil en folletos turísticos portugués-inglés: cerca del paraíso y lejos de la civilización
}

Lélian Silveira

(CEFET/RJ - Petrópolis), Brasil

lelian.silveira@hotmail.com

Danielly Leal

(CEFET/RJ - Petrópolis), Brasil

daniellydasilvaleal@gmail.com
DOI: https://doi.org/10.18472/cvt.20n3.2020.1831

Redalyc: http://www.redalyc.org/articulo.oa?

$\mathrm{id}=115464747005$

Recepción: 16 Junio 2020

Aprobación: 27 Noviembre 2020

\section{Resumo:}

As brochuras promocionais turísticas são os principais veículos de comunicação entre a oferta e a procura no mercado turístico. Com o principal objetivo de converter o potencial visitante em verdadeiro turista, na maioria das vezes, oferecem ao público o primeiro contato com o local a ser visitado e, com intuito de o diferenciar, selecionam imagens que contribuem para (re)criar ou reforçar estereótipos. Relativamente ao Brasil, as representações carregam marcas do passado colonial exotizado. Assim, considerando a relevância da temática relativa ao turismo e sobre a imagem do Brasil, este estudo tem como objetivo investigar a representação visual do país com base nas brochuras turi\#sticas selecionadas nas operadoras de viagens portuguesas e inglesas nos anos 2019, 2020 e 2021. Neste contexto, verifica-se que o país é representado a partir de cartografias imaginativas distintas, centradas na cultura urbana, paisagem natural e social humana. Além disso, cada uma dessas cartografias fornece um conjunto de referências responsáveis pela caracterização dos destinos brasileiros.

Palavras-Chave: Brasil, Representação, Turismo.

\section{ABstract:}

Promotional tourist brochures are the main source of communication between offer and demand in the tourist market. With the main objective of converting the potential visitor into a true tourist, in most cases, they will offer to the public the first contact with the place to be visited and, in order to differentiate it, they select images that contribute to (re)create or reinforce some stereotypes. Regarding to Brazil, these representations carry symbols from the exotic colonial past, an example of reality that already crossed a number of cultural expressions of the country, even long before the tourist promotion itself.

KEYWORDS: Brazil, Representation, Tourism.

\section{RESUMEN:}

Los folletos turísticos promocionales son el principal medio de comunicación entre la oferta y la demanda en el mercado turístico. Con el objetivo principal de convertir al visitante potencial en un verdadero turista, en la mayoría de los casos, ofrecen al público el primer contacto con el lugar a visitar y, para diferenciarlo, seleccionan imágenes que contribuyan a (re)crear o reforzar estereotipos. En relación con Brasil, las representaciones llevan marcas del exótico pasado colonial, una realidad que, mucho antes de la promoción turística, ya cruzó las diversas formas de expresión cultural del propio país.

Palabras clave: Brasil, Representación, Turismo.

\section{INTRODUÇÃo}

Representações do Brasil nas brochuras turísticas luso-inglesas: próximas do paraíso e distantes da civilização 
A construção da imagem do Brasil passou por tortuosos caminhos. O que se tem hoje é o resultado de um longo processo construído durante séculos, com raízes históricas e sociais, que apesar de aparentemente harmônico foi também construído com base na naturalização de estruturas de poder (Schwarcz, 2019).

Neste contexto, as impressões deixadas pela literatura de viagens, pelas narrativas dos padres jesuítas que desembarcaram no Brasil nos primeiros anos de colonização, cronistas, viajantes e, mais tarde, a própria produção intelectual, corroboraram para as representações exóticas do Novo Mundo e, posteriormente, para formação da imagem do país. Numa projeção imaginativa da visão edênica, ao Brasil foi atribuída a lenda dourada, o próprio "Paraíso Terreno", o "Eldorado" exuberante de riquezas e povoado por habitantes fabulosos.

A literatura colonialista, de formação catequética, encarregou-se de ratificar a superioridade europeia por meio da expansão da fé. As narrativas dos padres jesuítas que desembarcaram no Brasil - Manuel da Nóbrega, José de Anchieta, Fernão Cadim, entre outros - não apenas reconheceram na colônia os atributos de paraíso, mas evidenciaram a inferioridade e irracionalidade dos povos indígenas. Da mesma forma, os primeiros cronistas viajantes portugueses, ao aprofundarem seus conhecimentos sobre a colônia, com intuito de inventariar os recursos naturais para, em seguida, comercializá-los, o fizeram por comparação à civilização europeia, testemunhando o exotismo e a estranheza do Novo Mundo.

Não obstante o controle português, o território brasileiro também foi sendo visitado por inúmeros viajantes estrangeiros interessados, sobretudo, na riqueza e nos produtos passíveis de comercialização. No entanto, mediante a expansão das teorias evolucionistas, começaram a surgir as primeiras imagens de um território decrépito e isolado, situado na periferia do mundo civilizado. Além disso, a literatura nacional participou da ratificação do domínio europeu ultramar, criando estruturas que sustentavam a prática imperial. Com efeito, diversos escritores, cronistas, romancistas e historiadores, entre outros, acolheram a diferenciação básica entre a colônia e a metrópole como ponto de partida para a formação do caráter nacional, refletindo diretamente na forma como o país passou a ser representado.

No âmbito do turismo, a promoção do país esteve, por décadas, ligada à imagem mítica fundadora do país, reproduzida nos materiais de divulgação turística. Ainda hoje, a imagem idílica do paraíso terrestre é usada na tentativa de persuadir o turista a atentar para o lugar ideal, utópico, distante de todas as dificuldades e insatisfações. De maneira geral, aos visitantes são apresentadas grandes estruturas de lazer, modernos equipamentos hoteleiros e ampla oferta de serviços “all inclusive”, dentro de padróes de conforto e comodidade estabelecidos e importados da Europa e dos Estados Unidos.

Neste contexto mercadológico, as brochuras de divulgação turística são veículos de comunicação entre as operadoras e o potencial turista, com o principal objetivo de converter um potencial visitante em um verdadeiro turista. Segundo Lima e Palacios (2019, p. 133) "a comunicação turística surge no contexto de midiatização globalizada, como elemento chave na diferenciação dos destinos”. No entanto, Caton e Santos (2008) argumentam que, em geral, a mídia reflete e perpetua o discurso colonialista através de padrões binários entre o Ocidente e os Outros, suportando uma ideologia de poder, visto que as ferramentas de promoção turística também podem ser entendidas como discursos, pelos quais mensagens linguísticas e visuais são estrategicamente utilizadas para persuadir na tomada de decisão dos potenciais turistas (Hassan, 2014). Embora aparentemente inócuo na sua função principal de atrair visitantes, os materiais - textos e imagens - utilizados na promoção turística são fontes de mensagens subliminares, reforçando a percepção de um mundo exótico e cheio de promessas (Chetty, 2011).

Sob a perspectiva dos Estudos Culturais e do percurso histórico que conduziu a formação da imagem do país ao longo dos séculos e, ainda, considerando a importância de realização de estudos sobre a imagem do Brasil no turismo, este artigo tem como objetivo investigar a representação do Brasil a partir das mensagens visuais nas brochuras de promoção turísticas selecionadas nas operadoras de viagens portuguesas e inglesas nos anos 2019, 2020 e 2021. 
Por meio da análise de conteúdo e da abordagem semiótica foi possível identificar o que se designou indistintamente, por cartografias ou paisagens culturais imaginativas das representações do Brasil, centradas em três dimensões: cultura urbana, paisagem natural e uma vertente social humana. Em linhas gerais, as cartografias ou paisagens forneceram um conjunto de referências responsáveis pela caracterização dos destinos: a cartografia da cultura urbana vinculou-se diretamente com o patrimônio material e imaterial; a paisagem natural relacionou-se com a forma como a natureza foi apresentada, as múltiplas possibilidades do visitante vivenciar experiências e os espaçoos "turistificados" que suportam a atividade turística; ja\# a cartografia social humana ligou-se a origem, ao estilo de vida, ao comportamento e as crenças do povo brasileiro.

\section{O JARDIM DAS DELÍCIAS EM TERRITÓRIO BRASILEIRO}

No Brasil, os portugueses depararam-se com uma paisagem verdadeiramente edênica, repleta de símbolos conhecidos desde a Idade de Ouro. Neste momento, a novidade, a estranheza e a exuberância da natureza corroboraram a ideia de este não ser, portanto, "o novo, nem o outro, mas sim o mundo previsto desde sempre ambicionado e incessantemente procurado" (Seixas, 2003, p. 14). Assim, partindo da perspectiva do homem do século XVI, o imaginário sobre o paraíso determinou substancialmente a primeira visão dos autores que assim consideraram ter aflorado um Jardim das Delícias em território brasileiro. Noutros termos, os primeiros escritos, cartas e relatos de viagens sobre as novas terras traduziram o fascínio dos autores portugueses do século XVI por esta outra realidade estabelecida a partir do Jardim Sagrado, além de contribuírem para a compreensão e a classificação do Novo Mundo.

Destarte, por conveniências políticas e diplomáticas, o pouco interesse em divulgar a nova terra e, ainda, a dependência de censores e impressores portugueses, fizeram com que as crônicas sobre o "descobrimento" e boa parte da História do Brasil só fossem divulgadas tardiamente. Com efeito, obras como a Carta do Descobrimento, de Pêro Vaz de Caminha e a Carta do Mestre João Farás permaneceram arquivadas no Arquivo Nacional da Torre do Tombo, em Lisboa, por três séculos.

Dado o desconhecimento das terras brasileiras e da cultura dos índios, ao longo do século XVI surgiram poucas, mas minuciosas descrições acerca das novidades com que os portugueses se depararam. Dentre os primeiros viajantes a documentar suas impressões destacaram-se os jesuítas por meio da literatura de formação catequética e do espírito missionário de expansão da fé. Padre Manuel da Nóbrega (1517-1579), através da correspondência com o clérigo superior, relatou todo o período em que residiu na colônia, o que mais tarde originou a coletânea: Cartas Jesuíticas I - Cartas do Brasil (1549-1560). O jesuíta foi enviado ao Brasil em 1549, com o intuito de participar da $1^{a}$ Missão de Evangelização. Contudo, despendeu grande parte do seu tempo descrevendo as riquezas naturais do território brasileiro e, principalmente, os modos e os costumes das comunidades indígenas brasileiras com as quais manteve contato, no intuito de catequizálas e torná-las dignas do reino de Deus.

Anos mais tarde, o jesuíta José de Anchieta (1534-1597) foi igualmente enviado ao Brasil em missão evangelizadora. $\mathrm{Na}$ obra intitulada Cartas Jesuíticas III - Cartas, informações, fragmentos históricos e sermões, Anchieta transmitiu a imagem de um território extremamente formoso e aprazível, corroborando a visão paradisíaca. Entretanto, em Portugal, a notícia do "descobrimento" do Brasil só saiu impressa, pela primeira vez, na segunda metade do século XVI, quando historiadores quinhentistas resolveram relatar a formação do império português no Oriente (Pereira, 1999). Assim, em 1576, o historiador e cronista português Pêro de Magalhães Gândavo (1540-1579) redigiu a História da província de Santa Cruz a que vulgarmente chamamos de Brasil, na qual o autor propagou as qualidades da colônia respeitantes ao clima, aos recursos naturais existentes e, principalmente, às possibilidades de desfrute da terra recém-descoberta. $\mathrm{Na}$ obra, a natureza edênica, com frequência, foi empregada para fazer jus às formas pródigas e luxuriantes presenciadas. 
Já o historiador português Gabriel Soares de Sousa (1540-1591) realizou um minucioso inventário da fauna e flora brasileira em Notícia do Brasil ou Tratado descritivo do Brasil em 1587, demonstrando-se deslumbrado com a grandeza e a fertilidade da terra, mas também indignado com o descuido dos reis passados. Da mesma forma, o padre jesuíta português Fernão Cardim (1549-1625) relatou sua experiência em terras brasileiras entre os anos 1583 e 1601 na obra Tratados da terra e gente do Brasil, permitindo a Portugal ter um conhecimento detalhado das riquezas naturais e do espaço geográfico brasileiro. Nos primeiros relatos revelaram-se as primeiras impressões da "terra nova", inicialmente quanto à sua grandeza, diversidade e aos aspectos naturais. Logo, constatou-se o caráter edênico da descoberta: papagaios e araras, tucanos e tatus, onças, cobras e macacos, além de índios, naturalmente contra um fundo verdejante, foram as primeiras imagens fixadas pelo olhar europeu sobre este pedaço do novo mundo, que de imediato seduziu os navegantes com suas cores e sua exuberância (Teixeira, 2000).

No primeiro momento, a partir do referencial bíblico, a admiração pela natureza estendeu-se também à moral, posto que os autores procuraram transmitir a ideia de o Mundo Novo se assemelhar a um ambiente livre de maldade e trabalho duro - "eles não lavram nem criam" (Castro, 2008, p. 111) -, uma vez que a própria terra ofertava de forma generosa todos os recursos necessários para uma vida saudável e abundante. A natureza dadivosa, o exotismo, a beleza e a variedade da flora e fauna dessas paisagens ignotas levaram missionários, colonos e viajantes portugueses a descreverem o Brasil como sendo verdadeiramente o Jardim das Delícias. Além da contribuição das antigas crenças na existência do Éden sobre o imaginário do Novo Mundo, os cronistas demonstraram que, embora no Ocidente, o Brasil mantinha intacto todos os indícios das descrições medievais do paraíso (Seixas, 2003).

Como tal, os primeiros missionários e cronistas portugueses que visitaram a colônia durante o século XVI deslumbraram-se com a natureza dadivosa e corroboraram a visão edênica ao constatar sua geografia. Além disso, nota-se nos depoimentos dos missionários e cronistas do século XVI a presença dos mesmos elementos que, durante toda a Idade Média, apresentavam-se como distintivos da paisagem paradisíaca ou pareciam denunciar a sua proximidade imediata: temperaturas amenas, saborosos frutos, terras férteis, águas frescas, seres estranhos, metais preciosos, entre outros. Assim, o paraíso quinhentista manteve válidos os símbolos edênicos tão comuns nas descrições medievais do Jardim do Éden. Destarte, ainda que confusamente, uma nostalgia do mundo desaparecido parece ter acompanhado os navegadores, missionários e cronistas portugueses "quanto à esperança de magníficos tesouros acrescentavam a de aparições hostis ou fabulosas” (Seixas, 2003, p. 37).

Embora favorecido pela salubridade do clima, pela abundância das águas, pela exuberância da flora e fauna e pela longevidade de sua gente, o Brasil pareceu, aos olhos do Velho Mundo, ora como "terra abençoada", ora como território habitado por selvagens. As características apontadas pelos primeiros cronistas e jesuítas portugueses moldaram o ambiente brasileiro e perduraram, até certo ponto, em suas posteriores representações. A partir da propagação dos modelos científicos deterministas e das teorias raciais elaboradas na Europa, o modo de olhar o Brasil sofreu algumas modificações, posto que o clima e a miscigenação racial transformaram-se na grande mácula dos trópicos.

\section{O Brasil AOS OLHOS DOS VIAJANTES ESTRANGEIROS: DISTANTE DA CIVILIZAÇÃo}

Apesar do sigilo português, o isolamento geográfico e a proibição de forasteiros em terras brasileiras, as primeiras notícias e representações da nova terra foram registradas em mapas, diários, crônicas, cartas e relatos por estrangeiros que alcançaram a costa brasileira por acaso, curiosidade, cobiça ou missão. Logo após o "descobrimento" do Novo Mundo e ao longo do século XVI, as narrativas de ilustres viajantes, corsários, religiosos, cronistas e aventureiros foram sendo publicadas na Europa com o intuito de apresentar aos leitores as virtudes e os defeitos de uma terra, muitas vezes comparada ao Jardim das Delícias ou aos arredores do inferno. 
Enquanto Portugal voltava seus interesses para o Oriente na busca por especiarias, durante longos anos, marinheiros, piratas e viajantes de outras partes da Europa, sedentos por riquezas, curiosidade e conhecimentos, invadiram o vulnerável litoral da colônia portuguesa, desafiando o Tratado de Tordesilhas, com o objetivo de traficar o pau-brasil, obter informações sobre a terra e as espécies exóticas da flora e fauna brasileira. Assim, inúmeros viajantes como Sebastião Caboto, Roger Barlow, Richard Hakluyt, Villegaignon, André Thevét, Jean Léry, Anthony Knivet, William Dampier, Bougainville, Gonneville, entre outros, revelaram os mistérios do Mundo Novo para além das fronteiras lusitanas, ao terem seus relatos de viagens publicados na própria época em que foram escritos.

A primeira viagem de que se tem notícia de ingleses no Brasil foi realizada pelo comandante Sebastião Caboto (1476-1557) em 1526. Nesse mesmo ano, partiu de Sanlúcar de Barrameda, no Sul da Espanha, uma frota de cinco embarcações e, aproximadamente, duzentos tripulantes, com destino a Spice Islands, nas Molucas. Entretanto, o comandante Caboto, ao passar pelo Brasil, alterou o destino da viagem e permaneceu por quatro anos em explorações pelo Rio da Prata e pelo Rio Paraná em busca de riquezas minerais. Na mesma frota esteve presente o inglês Roger Barlow com a missão de levar de volta os mapas que descreviam as rotas marítimas e abririam o comércio inglês. No seu retorno à Inglaterra, Barlow narrou a viagem de exploração pelo Rio Paraná no primeiro livro inglês sobre o Novo Mundo após os "descobrimentos" - A Brief Summe of geographie -, cujo manuscrito foi oferecido ao rei inglês Henrique VIII em 1540 (Hue, 2013).

Richard Hakluyt (1552-1616) foi outro personagem inglês interessado nos relatos de viagens sobre o Mundo Novo. Ao publicar The principal navigations, voyages, traffiques and discoveries of the English Nation, em 1600, Hakluyt auxiliou a revelar o momento em que o Novo Mundo passou a despertar os interesses e a fazer parte dos projetos de conquista da Inglaterra. Hakluyt foi uma figura ligada diretamente à rainha Elizabeth I e responsável pela organização de uma coletânea de viagens com intenções políticas de legitimar o direito inglês às explorações dos mares do Sul, até então exclusivos das coroas portuguesa e espanhola. Da mesma forma, o escritor inglês Samuel Purchas (1575-1626) publicou, em 1625, seus relatos de viagens - Hakluytus posthumus or Purchas his pilgrimes, containing a history of the world, in sea voyages and land travels, by Englishmen and others - em cinco volumes, com a intenção de atribuir ao inglês John Cabot (1450-1499) a descoberta da América e, ainda, nomear o continente por Cabotiana (França, 2012; Hue, 2013).

Os franceses, desde o final do século XVI, se destacaram na edição de relatos de viagens e traduções de livros sobre o Novo Mundo. Além disso, no ano de 1550, na cidade francesa de Rouen, às margens do rio Sena, índios a caráter, cercados de adereços e alegorias tropicais, foram os protagonistas involuntários de uma festa apoteótica, na qual o Brasil foi o grande enredo. (França, 2012).

Dentro deste contexto, começaram a circular na França algumas das principais narrativas do século XVI descritas aos olhos do Ocidente. O primeiro a ser impresso foi: Cópias de algumas cartas sobre a navegação do cavaleiro Villegaignon, publicado em Paris, em 1557, de autoria do piloto Nicolas Barré (1621-1686), descrevendo a sua navegação entre a Europa e o Brasil, e, sobretudo a instalação dos Franceses no Brasil. Na mesma época, o frade franciscano e cosmógrafo do rei da França, André Thévet (1516-1590), narrou sua permanência no Brasil, em Les singularitez de la France Antarctique (1558). Mais tarde, na cidade portuária de La Rochelle, no ano de 1578, Jean de Léry (1536-1613) publicou Histoire d'un voyage fait en la terre du Brésil, descrevendo a bondade do ar, a abundância de animais, a variedade de aves, a formosura das árvores e das plantas, a excelência das frutas e as riquezas que embelezam o território colonial. (França \& Raminelli, 2009; França, 2012; Palazzo, 2012).

Em 1557, foi publicado na Alemanha o livro Duas viagens ao Brasil, título abreviado de Verdadeiras histórias e descrição de um país habitado por homens selvagens, nus, ferozes e antropófagos, situado no Novo Mundo, de autoria do alemão Hans Staden (1525-1576). Além disso, quarenta e sete gravuras ilustraram a obra de Staden, abordando os costumes dos índios tupinambás e rituais canibalescos. O alemão também 
dedicou algumas páginas aos animais da nova terra e descreveu a crueldade manifestada nos rituais indígenas (França \& Raminelli, 2009).

Ao longo do século XVII, a metáfora da primavera eterna, em conjunto com o clima ameno, salubre, e a prodigalidade da terra não abandonaram as narrativas de viagem sobre o Brasil. Em junho de 1612, mais uma vez, uma expedição francesa, comandada pelos oficiais Daniel de La Touche (1570-1631) e François de Razilly (1578-1622), desembarcaram no Brasil com o objetivo de instalar uma feitoria em São Luís do Maranhão e fundar uma colônia francesa no Novo Mundo - a França Equinocial. A história do empreendimento foi registrada nas várias cartas e narrativas produzidas pelos missionários capuchinhos que acompanharam a expedição com a missão de pregar a fé e promover a salvação das almas dos nativos: Claude d'Abbeville (15?-1632) e Yves d'Évreux (1577-1632) nas suas respectivas obras Histoire de la mission des pères capucins en l'isle de Maragnan et terres circonvoisines (1614), Voyages dans le nord du Brésil fait durant les années 1613 et 1614 par le Père Yves d'Évreux (1613), narraram sobre a primavera eterna, as riquezas infinitas, a diversidade de pássaros, peixes e insetos, entre outros animais, ora exóticos, ora familiares, que encontraram no Novo Mundo (França \& Raminelli, 2009; França, 2012).

A partir de 1621, os holandeses também passaram a se interessar pelo território brasileiro, por razões políticas e diplomáticas, posto que a guerra com a Espanha bloqueou o comércio holandês de alguns produtos não disponíveis no Norte da Europa (Melo, 2012). Apesar da ocupação holandesa no Nordeste durar somente vinte e quatro anos, o período produziu diversas narrativas acerca da dominação colonial holandesa: fontes administrativas da Companhia Holandesa das Índias Ocidentais, inventários sobre natureza, processos de inquisição e crônicas de guerras (Vainfas, 2012). Como testemunho da ocupação holandesa, tem-se o Diário de um soldado da Companhia das Índias Ocidentais (1629-1632), redigido pelo militar Ambrosius Richshoffer (1612-?); o livro do viajante Joan Nieuhof (1618-1672), Memorável viagem marítima e terrestre ao Brasil (1682), no qual o autor defendeu a atuação do governo holandês no Brasil e faz observações sobre a flora e fauna brasileira e, ainda, o livro L'histoire de la dernière guerre faite au Brésil entre les Portugais et les Hollandais (1651) - narrativa da experiência vivenciada pelo francês Pierre Moreau como funcionário da Companhia Holandesa das Índias Ocidentais (Melo, 2012). O pintor holandês Frans Post (1612-1680) esteve presente na comitiva liderada por Nassau em 1637 e produziu muitas paisagens sobre o Brasil com base nos próprios estudos, com o objetivo de divulgar a ação colonizadora holandesa no Velho Mundo.

No século XVIII, malgrado a persistência da ideia de clima temperado, o calor dos trópicos passou a incomodar o visitante estrangeiro e, sobretudo, a parecer-lhe inóspito e insalubre. Outrossim, a partir desse século, os viajantes com destino ao Brasil levaram consigo os princípios da classificação da natureza, procurando enquadrar a colônia nas categorias científicas da Nova História Natural criada pelo naturalista francês Georges-Louis Leclerc (1707-1788), também conhecido como Conde Buffon, dando início aos discursos mais desfavoráveis sobre a natureza tropical.

Com efeito, até o século XVIII, os relatos de viagens ajudaram a construir a imagem de um Brasil decrépito e isolado na periferia do mundo civilizado. No século XIX, o território brasileiro foi invadido por naturalistas e pintores viajantes que, devido aos interesses comerciais e políticos da época, permitiram que o Brasil fosse redescoberto e revelado pelo olhar de cientistas viajantes, que penetraram no sertão profundo pouco conhecido no Velho Mundo. Além disso, nos trabalhos dos viajantes que acompanharam as expedições científicas, destacou-se o Brasil mestiço, "não importando o sexo, a raça ou a condição social do indivíduo" (Schwarcz, 1993, p. 12).

A partir da transferência da Corte portuguesa para o Brasil, em 1808, Dom João VI decretou a abertura dos portos às nações amigas e a criação do Tratado de Comércio e Navegação, privilegiando a Inglaterra. Em outros termos, findaram-se séculos de isolamento e permitiu-se que os estrangeiros pudessem frequentar os portos da colônia e desvendar o interior do território. 
A partir de 1816, transferiram-se para o Brasil a Missão Artística Francesa, liderada pelo acadêmico Joaquim Lebreton (1760-1819), e o grupo composto pelo arquiteto Auguste Henri Victor Grandjean de Montigny (1776-1850) e pelos pintores Nicolas-Antoine Taunay (1755-1830) e Jean-Baptiste Debret (1768-1848). Destarte, a Missão contribuiu não apenas para o desenvolvimento da arte, a formação de artistas e a construção da iconografia brasileira, mas principalmente desempenhou o papel político na criação de um ambiente artístico de corte e afirmação da presença do Estado português no Novo Mundo. Dessa forma, inspirado na moda francesa, o Estado investiu na construção de imagens edificantes do regime monárquico (Knauss, 2012).

A experiência dos artistas nos trópicos resultou nos mais relevantes acervos produzidos sobre o território brasileiro em séculos de história. $O$ pintor francês Nicolas-Antoine Taunay dedicou-se ao ofício de registrar e catalogar a geografia e o cotidiano do Rio de Janeiro. A topografia, as ruas, as diferentes atmosferas dos bairros, os escravos, os cortejos, os personagens da corte etc. operaram como elementos centrais de suas obras. Já o artista francês Jean-Baptiste Debret destacou-se como um dos mais importantes cronistas estrangeiros a lançar o seu olhar sobre a paisagem natural do Brasil no período colonial. Suas crônicas sobre o Rio de Janeiro, apesar de direcionadas ao público francês e carregadas de ironia e exotismo, foram relevantes para a história do país, principalmente pelas observaçóes sobre o cotidiano urbano e os costumes populares, sobretudo na apresentação da sociedade escravocrata da época (Knauss, 2012; Alvim, 2012).

Em 1817, por ocasiáo do casamento do Imperador D. Pedro I (1798-1834) com a Arquiduquesa Maria Leopoldina de Áustria (1797-1826), desembarcou no Rio de Janeiro um grupo de cientistas austríacos e alemães que integraram a primeira expedição estrangeira dedicada a desenvolver estudos e pesquisas de história natural nos domínios portugueses. Com a duração de três anos e percurso de aproximadamente 10 mil km pelo território brasileiro, a expedição reuniu e transferiu para a Europa milhares de espécies da flora e fauna brasileira e um vasto material etnográfico sobre os povos indígenas com os quais mantiveram contato. Contudo, os naturalistas também relataram suas impressões sobre as virtudes e os defeitos do modelo de sociedade que se erguia no território. Os registros da expedição foram reunidos por Johann Baptist von Spix e Carl Friedrich von Martius nos três volumes da obra Viagem pelo Brasil nos anos de 1817 e 1820, publicados entre 1823 e 1831.

Até o final do século XIX, outros notáveis viajantes tiveram o Brasil como destino, entre eles o britânico Charles Darwin (1809-1882) esteve no país em 1833 como parte do itinerário de sua viagem ao redor do mundo, como naturalista e tripulante do navio Beagle. Darwin dedicou algumas páginas de seu diário ao Brasil e registrou seu encantamento pela natureza local, mas também sua indignação com a violenta e desigual sociedade escravocrata brasileira. Da mesma forma, em 1865, o cientista suíço Louis Agassiz (1807-1873), no comando de uma viagem científica - Expedição Thayer - sob os auspícios do governo dos Estados Unidos da América, realizou pesquisas pelo Rio de Janeiro, Minas Gerais, Nordeste e Amazônia, publicadas na obra A Journey in Brazil, em 1868. Louis Agassiz teve como principal objeto a sociedade brasileira e defendeu a tese na qual a miscigenação era um fator de degeneração da humanidade; os negros eram inferiores e deveriam ser mantidos apartados da civilização: "(...) qualquer um que duvide dos males da mistura de raças, e inclua por mal-entendida filantropia, a botar abaixo todas as barreiras que separam, venham ao Brasil” (Agassiz, 1868, p. 293).

O historiador inglês Henry Thomas Buckle (1821-1862) foi um dos mais representativos intelectuais que caracterizaram a literatura científica no final do século XIX. Apesar de nunca ter visitado o Brasil, Buckle, em sua obra História da civilização na Inglaterra (1857-1865), dedicou algumas páginas à formação do caráter brasileiro e, ainda, relacionou os principais conceitos científicos eurocêntricos de sua época às civilizações dos trópicos (Sodré, 1965). Em seus estudos sobre o Brasil, baseou-se nas investigaçóes de alguns naturalistas viajantes que passaram pelo Brasil - Spix, von Martius, Charles Darwin, entre outros. Ao considerar o modelo de civilização inglês como referencial de desenvolvimento e utilizar o determinismo ambiental, privilegiou o continente europeu e desqualificou as regióes de clima quente, dividindo o mundo em duas grandes regiões: a 
Europa e a não-Europa (Romero, 2016). Na concepção de Buckle (1857), o Brasil, não obstante o empenho e colaboração das civilizações europeias avançadas e a fertilidade da natureza, permaneceria permanentemente análogo ao barbarismo, em virtude das pressões naturais, e da consequente ignorância do povo: "o Brasil todo, apesar das imensas vantagens aparentes, tem permanecido sempre como incivilizado os habitantes vagando como selvagens, incapazes de resistirem àqueles obstáculos que a própria generosidade da natureza colocou em seu caminho" (Buckle, 1857, p. 75).

Assim, as viagens de exploração de estrangeiros no Brasil alimentaram o imaginário europeu sobre o país por mais de três séculos. O conteúdo das narrativas de viagens faz parte da pré-história da imagem do Brasil e, além disso, contribuíram para a formação da identidade nacional brasileira. De forma polarizada se deram as primeiras representações sobre o território colonial. A natureza dadivosa concedeu ao Novo Mundo o rótulo de paraíso abundante de todos os recursos naturais escassos na Europa, entretanto, o paraíso era habitado por estranhas criaturas.

\section{CoRpus DE PESQuisa E Metodologia}

O corpus de pesquisa apresentado constitui-se por brochuras turísticas do Brasil recolhidas nas operadoras de viagens portuguesas e inglesas, nos anos correspondentes às temporadas 2019, 2020 e 2021. Assim, foram analisadas 07 brochuras portuguesas e 04 brochuras inglesas, totalizando 11 brochuras turísticas, conforme apresentado no quadro 1 .

\section{QUADRO 1}

Brochuras turísticas produzidas pelas operadoras de viagens participantes na investigação

\begin{tabular}{|c|c|c|c|c|c|c|c|c|}
\hline Portugal & 2019 & $\begin{array}{c}2019 / \\
2020\end{array}$ & 2020 & $\begin{array}{l}202 / \\
2021\end{array}$ & Inglaterra & 2020 & $2020 / 2021$ & \multirow[t]{5}{*}{ Total } \\
\hline $\begin{array}{l}\text { Abreu } \\
\text { Viagens }\end{array}$ & & 1 & 1 & 1 & $\begin{array}{l}\text { Audley } \\
\text { Travel }\end{array}$ & & 1 & \\
\hline SolFérias & 1 & & 1 & 1 & $\begin{array}{l}\text { Llama } \\
\text { Travel }\end{array}$ & & 1 & \\
\hline \multirow[t]{2}{*}{ NorTravel } & 1 & & & & $\begin{array}{l}\text { On The Go } \\
\text { Tour's }\end{array}$ & 1 & & \\
\hline & & & & & Trailfilder's & 1 & & \\
\hline Total & 2 & 1 & 2 & 2 & & 2 & 2 & 11 \\
\hline
\end{tabular}

autores

A metodologia utilizada nesta investigação e\# de caráter exploratório e descritivo. No entanto, empregouse como critério a saturação da amostra, em que, solicitou-se às operadoras de viagens portuguesas e inglesas o material promocional sobre o Brasil, e deixou-se de solicitá-los quando se percebeu a repetic\#a\#o das informações e que o acréscimo de dados e informações na\#o alteraria a compreensão do fenômeno. Todavia, a análise na\#to empregou nenhum programa informático de análise de dados.

Antes de qualquer análise interpretativa das brochuras turísticas nos pai\#ses investigados, faz-se necessário uma referência a\# teoria metodológica empregada na exploração e análise do material. Neste caso, optouse pela utilização da análise de conteúdo (Bardin, 1991) e da abordagem semiótica (Barthes, 1982), uma vez que se apresentam como métodos adequados, principalmente porque permitiram acessar as realidades subjetivas das representações simbólicas envolvidas na percepção do Outro. Por outras palavras, a análise de conteúdo e a semiótica possibilitaram "tornar visível os alicerces ocultos da construção discursiva” (Cordeiro, 
2010, p. 137) nas brochuras turísticas. A partir de uma abordagem qualitativa e interpretativa considerou-se o conteúdo social e histórico sob o qual foram produzidos (Campos, 2004).

Sendo assim, na tentativa de identificar os principais atributos conferidos ao Brasil a partir de outros países europeus, o primeiro passo da pesquisa constituiu-se na análise de conteúdo, fundamentada em dimensões propostas por Bardin (1991): na descrição do material, ou seja, na análise de suas características, das imagens, sublinhando sua dimensão interpretativa e seus significados culturais. Apresentaram-se, ainda, processos de inferência e deduções lógicas, que permitiram na\#o apenas produzir suposic\#o\#es acerca das mensagens, mas identificar causas e conseque\#ncias de um determinado conteúdo, além de embasá-las em pressupostos teóricos (Campos, 2004). A partir da observação atenta dos conteúdos das brochuras turísticas, articulada com os objetivos desta investigação, observou-se que as referidas brochuras apresentavam o que o visitante poderia encontrar no destino, ou seja, os atrativos naturais, o patrimônio material e imaterial, a estrutura turística de apoio e, em alguns casos, o encontro com a população nativa.

$\mathrm{Na}$ fase seguinte, numa análise ainda mais fina, foi possível reagrupar as categorias e após uma exaustiva exploração e afunilamento das mensagens das referidas brochuras turísticas, emergiram três categorias distintas: cultura urbana, paisagem natural e uma vertente social humana, constituindo-se por cartografias culturais imaginativas de representac\#a\#o do Brasil. Em seguida, cada uma das cartografias, forneceu um conjunto de referências (sub-categorias) responsáveis pela caracterização dos destinos. A primeira paisagem a emergir foi a "cultura urbana" relacionando-se diretamente com o patrimônio material/imaterial. A segunda cartografia a emergir foi a "paisagem natural" referindo-se à forma como a natureza é representada (patrimônio natural e rural/ecológico), às múltiplas possibilidades de o visitante vivenciar experiências $\mathrm{e}$ aventuras e a estrutura que suporta a atividade turística. Por fim, a cartografia "social humana" resultou da ligação das categorias origem, estilo de vida, comportamento e crenças da população brasileira. Uma análise mais profunda e a articulação das cartografias e paisagens nos países investigados originaram em cartografias gerais relativas ao modo como o Brasil é representado nas brochuras turísticas analisadas, conforme quadro 2 .

QUADRO 2

Cartografias/paisagens e categorias gerais relativas ao Brasil

\begin{tabular}{|l|l|}
\hline Cartografias/Paisagens & Categorias gerais relativas ao Brasil \\
\hline Cultura Urbana & A rota do ouro \\
\hline Paisagem Natural & Um paraiso junto ao oceano \\
\hline Social Humana & Explosäo de alegria de suas gentes \\
\hline
\end{tabular}

autores

As referidas cartografias foram encontradas tanto nas mensagens verbais, através de palavras, como no contexto visual, veiculadas através de imagens. Entretanto, no caso específico desta investigação, por limitações de espac\#o, optou-se por apresentar apenas o conteúdo visual. Além disso, embora as brochuras turísticas possuam uma composição textual, elas são majoritariamente compostas por mensagens visuais, as quais têm um papel de destaque no tocante à representação publicitária turística.

Além da análise de conteúdo, a abordagem semiótica também contribuiu para a interpretação das imagens das brochuras turísticas investigadas. Enquanto a análise de conteúdo forneceu a base descritiva e interpretativa, resultando nas cartografias ou paisagens culturais imaginativas de representação do Brasil, a abordagem semiótica permitiu a investigação dos significados e simbolismos gerados por meio de um arranjo particular de sinais e da implantação de códigos culturais (Barker, 2003), ou, por outras palavras, a maneira como as imagens produziram sentidos. Desta forma, a partir de uma análise mais detalhada, encontraram- 
se um conjunto de signos culturalmente coerentes que, apesar de descontínuos, remeteram para significados globais dentro de uma descrição aprofundada (Barthes, 1982).

\section{Cartografias imaginativas luso-inglesas sobre o BrasiL}

Com base nas brochuras turísticas recolhidas nas operadoras de viagens portuguesas e inglesas nos anos correspondentes às temporadas de 2019, 2020 e 2021, verifica-se que o Brasil é representado a partir de três cartografias imaginativas distintas: cultural urbana, social humana e paisagem natural. Uma análise mais profunda e a articulação das cartografias imaginativas originaram em categorias gerais relativas ao modo como o Brasil e\# representado nas brochuras turísticas analisadas, conforme apresentado a seguir:

a) Cartografia Cultural Urbana: a rota do ouro

O conteúdo visual da cartografia cultural urbana das brochuras turísticas portuguesas evoca a metáfora da missão civilizadora do Estado português, reproduzindo a típica paisagem arquitetônica construída pelos portugueses nas suas antigas colônias. De forma indireta, ao refletir o próprio passado heroico e civilizador, o discurso contribui para (re)criar uma forte dependência cultural e, ao mesmo tempo, aumentar o sentimento de apropriação e familiaridade com o patrimônio material por parte do visitante, conforme as ilustrações 1 e 2 .

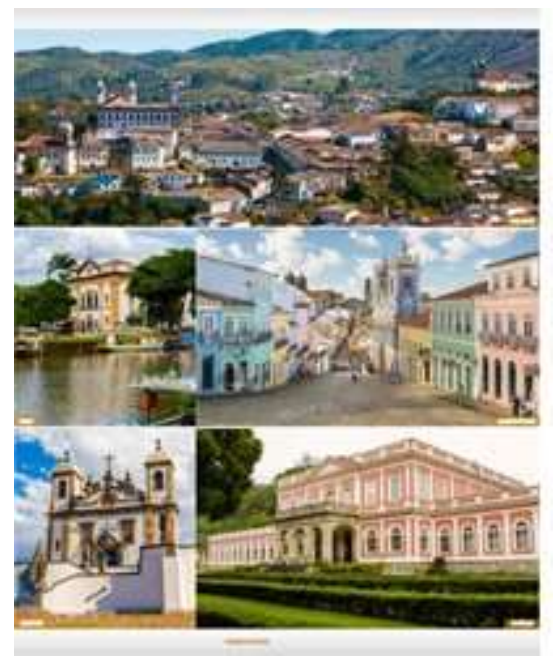

ILUSTRAÇÃO 1:

Brasil, rota do ouro

NorTravel, 2019 


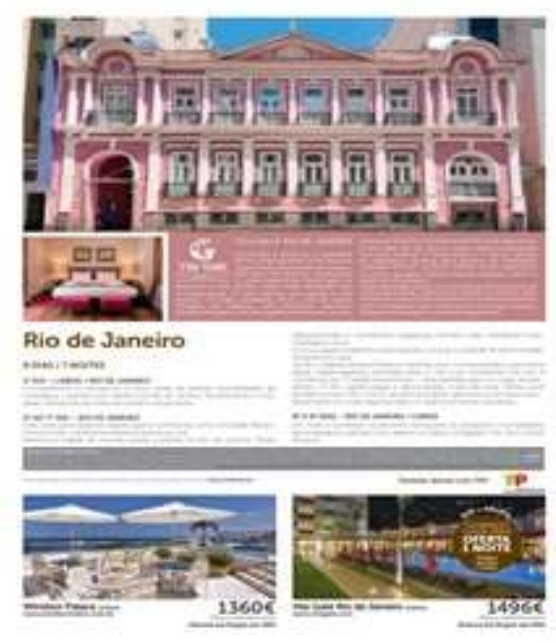

\section{ILUSTRAÇÃO 2: \\ Rio de Janeiro \\ Sol Férias, 2019}

De forma semelhante às brochuras turísticas portuguesas, o material promocional inglês também apresenta um conjunto de referências relacionadas à herança colonial, sugerindo a suspensão do tempo cronológico e uma viagem através da história colonial do país. Assim sendo, grande parte do patrimônio material do país é conservado dentro de um espaço colonial, desconsiderando qualquer modernidade que seja diferente daquela ofertada pela missão civilizadora portuguesa. Na busca de transmitir uma mensagem capaz de atrair visitantes, apresenta-se o que é atrativo e conveniente, muitas vezes perpetuando a ideologia do colonialismo, como pode ser observado nas ilustrações 3,4 e 5 .

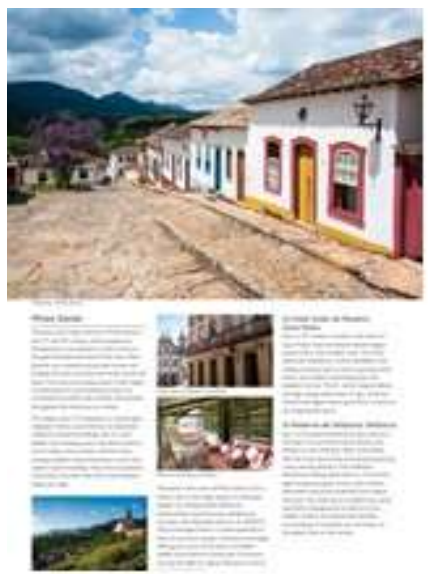

ILUSTRAÇÃO 3:
Minas Gerais.
Audley Travel, 2020/21 


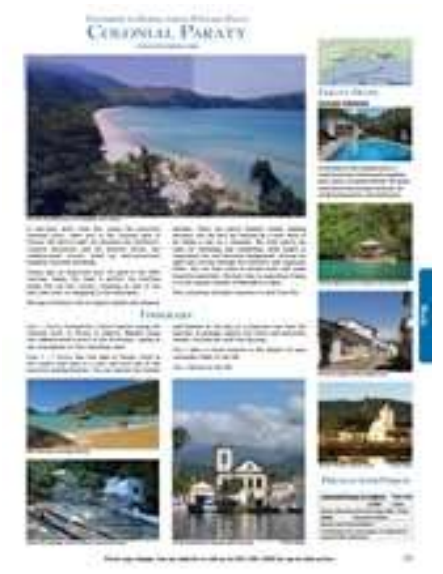

\section{ILUSTRAÇÃO 4: \\ Paraty Colonial \\ Llama Travel, 2020/21}

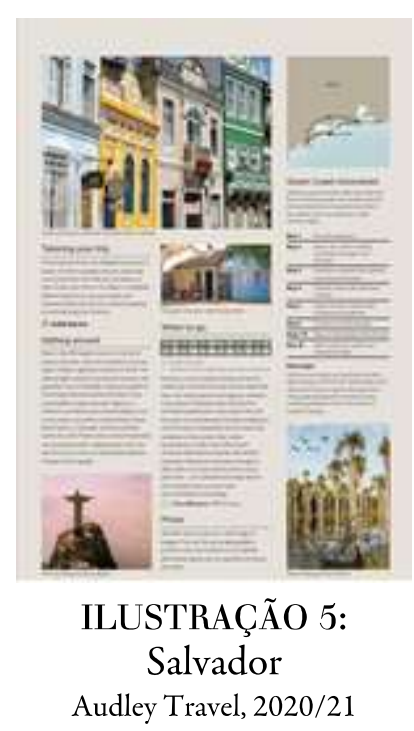

Entretanto, ainda que de forma modesta, a cartografia da cultura urbana das brochuras inglesas também funciona como centro de encontros, prevalecendo uma proximidade urbana. Assim, as ruas surgem como espaços vivos e locais de sociabilidade, assumindo uma dimensão exotizada. Ademais, embora as influências do colonialismo prevaleçam como principais elementos do patrimônio material, os traços de modernidade e contemporaneidade sugerem espaços urbanos dotados da estrutura necessária para receber os visitantes, conforme ilustrações 6 e 7. 


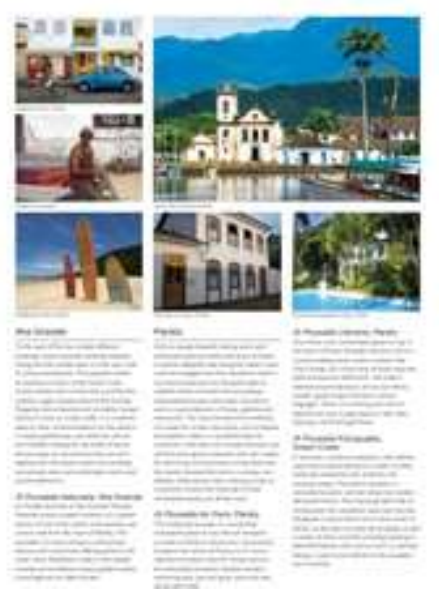

\section{ILUSTRAÇÃO 6: \\ Paraty \\ Audley Travel, 2020/21}

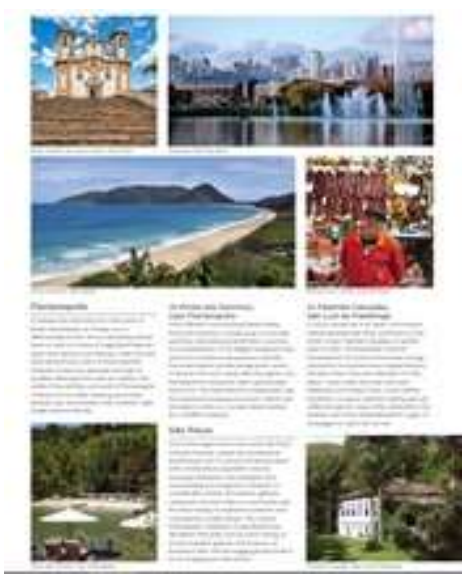

\section{ILUSTRAÇÃO 7:}

São Paulo

Audley Travel, 2020/21

b) Cartografia Social Humana: explosão de alegria das suas gentes

Apesar de poucas representações, a cartografia social humana nas brochuras portuguesas é afetada por estereótipos raciais e mitos coloniais, atribuindo o papel do Outro exotizado presente na encenação da prática da capoeira, na figura das baianas e na função imaginativa desempenhada pelos grupos indígenas. Soma-se, ainda, a forma de apresentação do estilo de vida da população brasileira a partir do clima de descontração, despojamento e euforia, conforme as ilustrações 8,9 e 10 . 
LÉLIAN SILVEIRA, ET AL. REPRESENTAÇ̃̃ES DO BRASIL NAS BROCHURAS TURÍSTICAS LUSO-INGLESAS: PRÓXIMAS ...

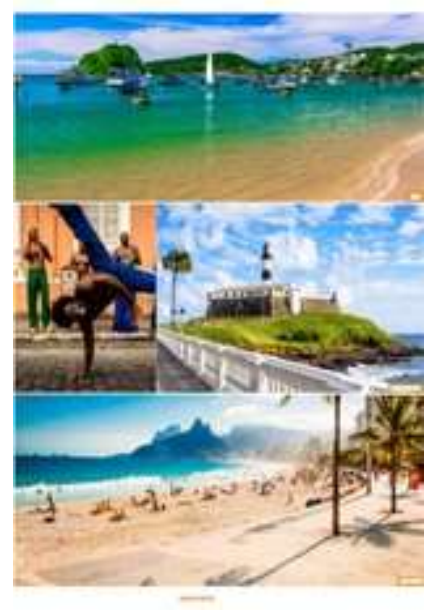

ILUSTRAÇÃO 8:

Brasil, cultura e praia

Nor'Travel, 2019
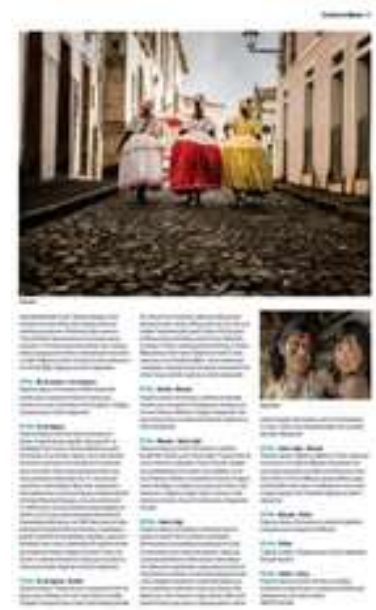

ILUSTRAÇÃO 9:

Exuberante Brasil

Abreu Viagens, 2019/20 


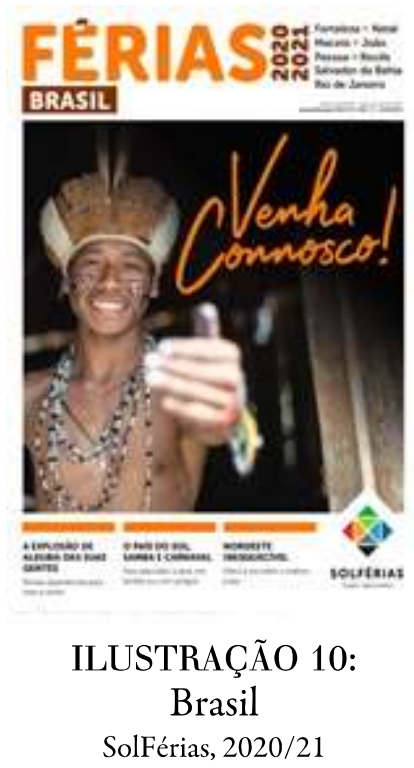

Aqui, o corpo também é produto das relações hierárquicas exercidas entre o turista europeu e o nativo. A distância social é marcada não somente pelo tom de pele, mas principalmente pela forma de expressão corporal, vestimentas e desempenho dos grupos humanos. Sendo assim, enquanto ao nativo é reservado a posição de exótico adereço cultural, ao visitante branco é atribuída a posição de espectador da cultura. Ademais, a presença de casais com fenótipos e vestimentas distintas indica que apesar do exotismo das manifestações culturais, o país está preparado para receber o potencial visitante, conforme ilustrações 11 e 12.

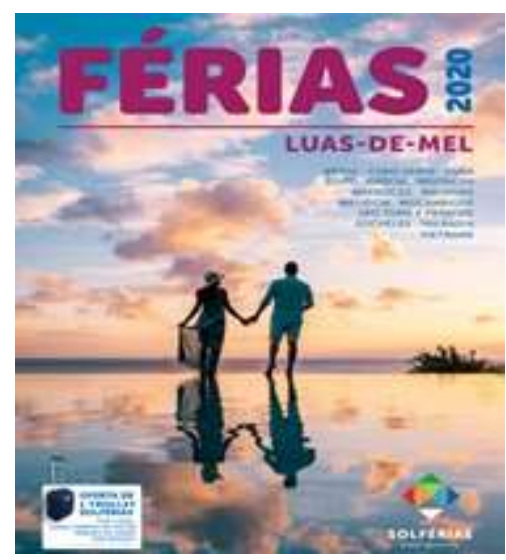

ILUSTRAÇÃO 11:

Lua-de-Mel

SolFérias, 2020 


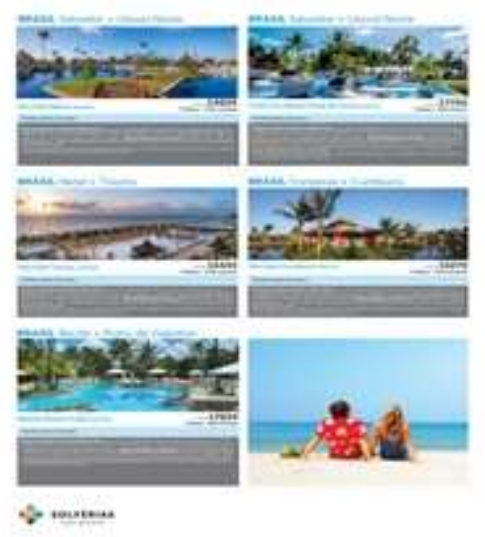

\section{ILUSTRAÇÃO 12: \\ Brasil \\ SolFérias, 2020}

De igual forma, a cartografia social humana representada nas brochuras turísticas inglesas também é marcada pelo exotismo das manifestações culturais miscigenadas. Neste caso, o conteúdo visual apela para a sensualidade feminina destacada pela mistura racial e pelos trajes carnavalescos ou, ainda, condicionada ao misticismo das religiões africanas através da representação das baianas e a prática da capoeira. Nesse contexto, o povo brasileiro é apresentado pela face das tradições culturais miscigenadas, corroborando a imagem do Outro exotizado e erotizado, suscitando a imaginação e o desejo sobre as mulheres brasileiras, conforme as ilustrações 13,14 e 15.

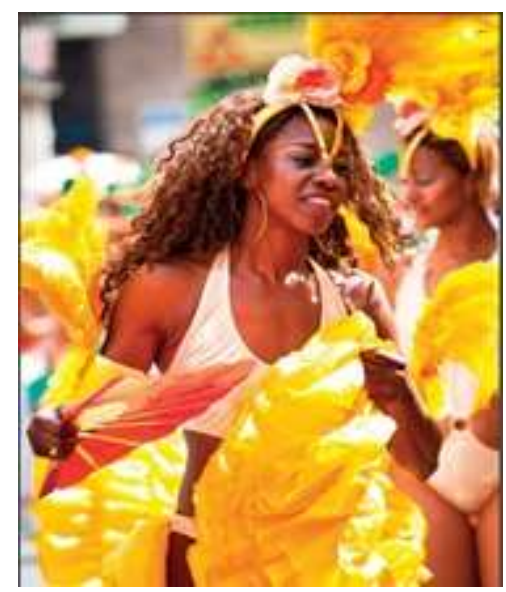

ILUSTRAÇÃO 13:

Brasil

Audley Travel, 2020/21 


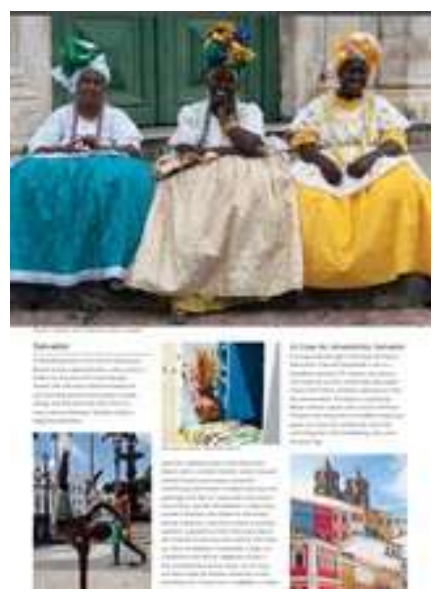

ILUSTRAÇÃO 14:

Salvador

Audley Travel, 2020/21

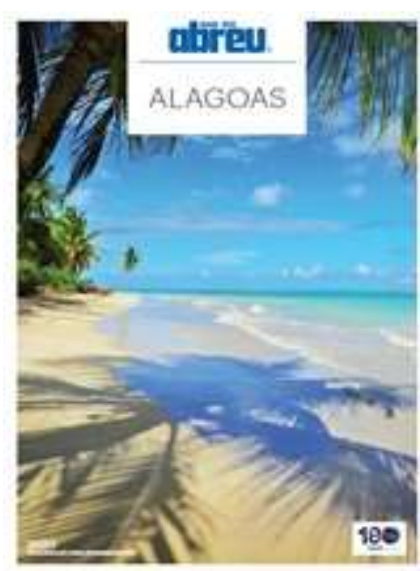
ILUSTRAÇÃO 15:
Rio de Janeiro
On The Go Tours, 2020

c) Paisagem Natural: um paraíso junto ao oceano

De maneira geral, o espaço dominante nas brochuras turísticas portuguesas é a paisagem natural fortemente marcada por um conjunto de referências relacionadas à exuberância dos atrativos naturais. Aqui, as imagens parecem reproduzir as primeiras representações do Novo Mundo ao refletirem os cenários paradisíacos outrora presentes nos discursos da igreja, na literatura de viagens e, mais tarde, na própria literatura nacional.

Entretanto, a paisagem natural, apesar de perpetuar a ideia de uma civilização construída sob o signo do atraso, da estagnação e da falta de progresso urbano, apresenta, na maioria das vezes, uma estrutura turística suficientemente moderna e confortável para atender os visitantes, conforme as ilustrações 16, 17 e 18 . 
LÉLIAN SILVEIRA, ET AL. REPRESENTAÇ̃̃ES DO BRASIL NAS BROCHURAS TURÍSTICAS LUSO-INGLESAS: PRÓXIMAS ...

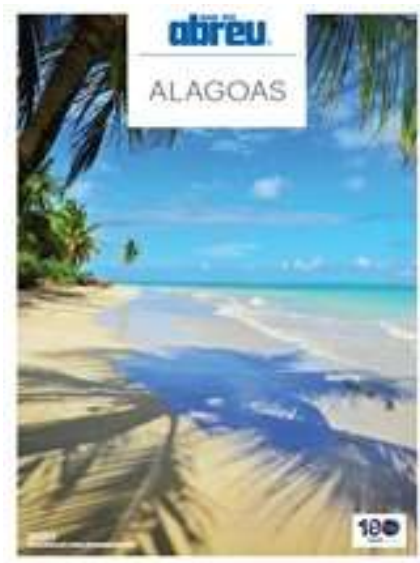

ILUSTRAÇÃO 16:

Alagoas

Abreu Viagens, 2020

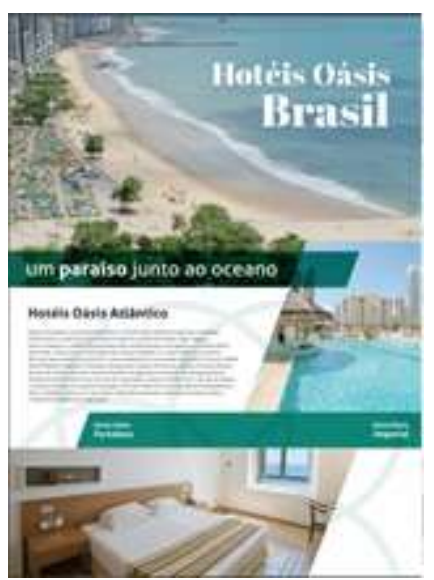

ILUSTRAÇÃO 17:

Hotel Oásis

SolFérias, 2019
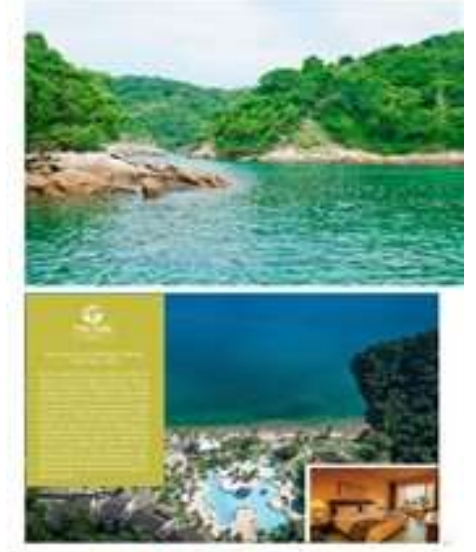

ILUSTRAÇÃO 18:

Brasil

SolFérias, $2020 / 21$ 
Ademais, os indicadores visuais da paisagem natural que representam o Brasil nas brochuras turísticas portuguesas também apresentam as múltiplas possibilidades de o visitante desfrutar e usufruir dessa terra exótica, sobretudo em espaços de aventura, conforme a ilustração 19.

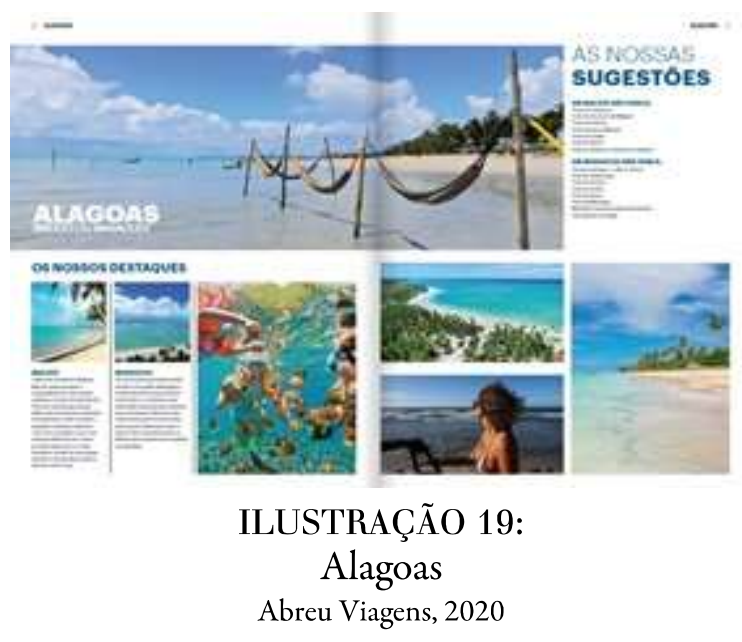

À semelhança das brochuras turísticas portuguesas, os indicadores visuais da paisagem natural nas brochuras inglesas apresentam o país como um destino aparentemente paradisíaco e selvagem. De maneira geral, o espaço dominante é composto por paisagens naturais, fortemente marcada por um conjunto de referências relacionadas à diversidade e exuberância dos atrativos naturais, sugerindo a fuga para a liberdade paradisíaca do Outro lugar. Todavia, as imagens parecem reproduzir não somente o encontro com o Outro primitivo, mas sobretudo as expedições exploratórias em busca por conhecimento sobre Novo Mundo vivenciadas no período colonial. Desta forma, as imagens funcionam como fator motivacional, reproduzindo o mito do ambiente selvagem repleto de animais exóticos, apresentando-se propício para viagens de aventura e exploração, conforme as ilustrações 20, 21 e 22.

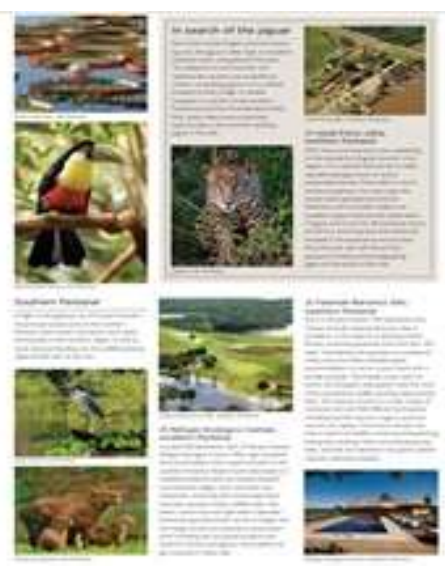

$$
\begin{gathered}
\text { ILUSTRAÇÃO 20: } \\
\text { Pantanal } \\
\text { Audley Travel, 2020/21 }
\end{gathered}
$$




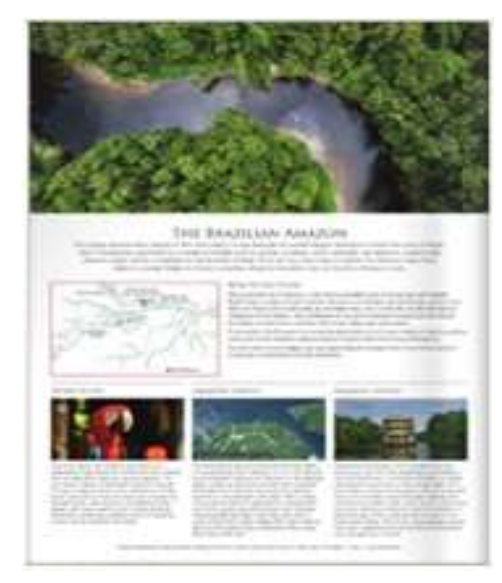

ILUSTRAÇÃO 21:

Amazônia

Trailfinders, 2020

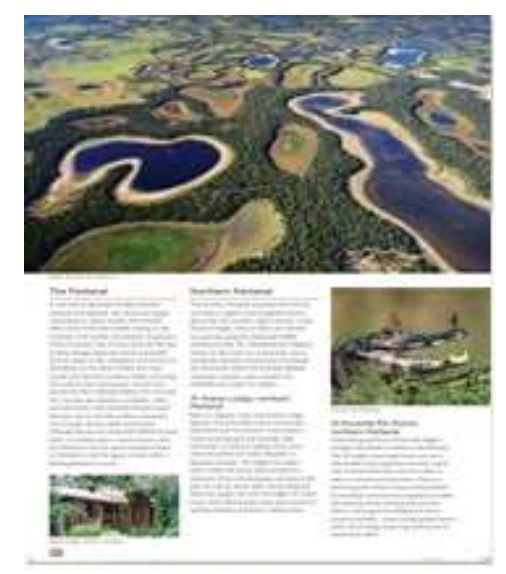

ILUSTRAÇÃO 22:

Pantanal

Audley Travel, 2020/21

Por fim, é possível observar imagens que sinalizam a possibilidade de encontro do visitante com a população nativa, por meio da presença de um pescador e moradores ribeirinhos, sendo assim, não só escapa a uma exposição controlada e higienizada como assume uma dimensão ainda mais exotizante. $\mathrm{Ou}$, ainda, à posição subalterna da população local, reservada ao espaço da pesca e trabalhos manuais, colocando-a em uma condição submissa frente ao visitante, conforme as ilustrações 23 e 24. 


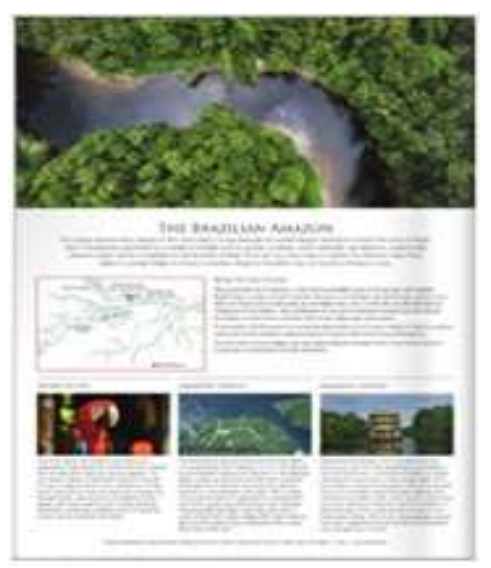

ILUSTRAÇÃO 23:

Amazônia

Audley Travel, 2020/21

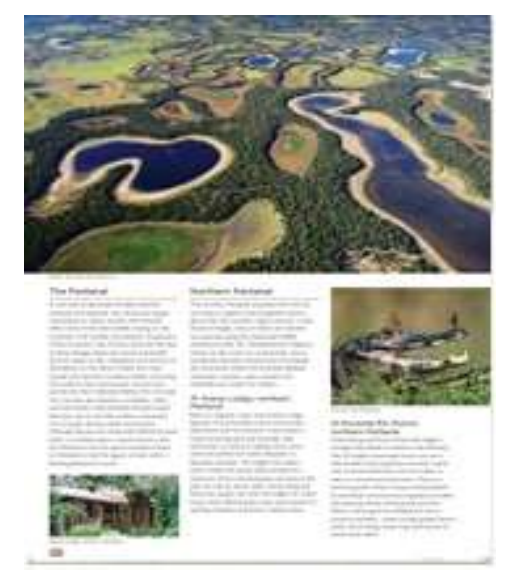

ILUSTRAÇÃO 24:

Manaus

Audley Travel, 2020/21

\subsection{Discussão dos resultados}

A publicidade turística além de antecipar e prometer a vivência de experiências, tem o papel de criar uma imagem atraente, através da utilização de recursos visuais e simbólicos. Entretanto, este modo de comunicação tende a confirmar e reativar estereótipos e formas de representação já massificadas. Ademais, muitas vezes as "imagens têm a ver mais com sua relação com o outro, com contraste em relação às expectativas do espectador, do que com o que são em si mesmas" (Lima \& Palacios, 2019, p. 135).

No caso das brochuras turísticas produzidas pelas operadoras de viagens de Portugal, as imagens ligadas à cartografia cultural urbana expõem o conteúdo de um país cristalizado dentro do próprio "eu" colonial, sem, contudo, passar por períodos de transformação e urbanização posteriores ao período colonial. $O$ patrimônio material brasileiro se detém às influências portuguesas, funcionando como uma espécie de extensão ou espelho do próprio lugar, resultando na produção de um "não-lugar" (Augé, 1994). Trata-se da tentativa de materializar a oferta sob a forma de um produto passível de apropriação/consumo. Ou melhor, uma estratégia de sedução de potenciais visitantes. No entanto, tal interesse não pode ser traduzido em contato real com o destino, uma vez que não ultrapassa, na maioria das vezes, a uma comunicação superficial dentro de um espaço de encenação turística.

Enquanto a Europa exerceu grande influência na arquitetura, nas artes e no "refinamento civilizacional", a miscigenação racial foi apresentada, sobretudo, através de forte componente da diversidade cultural do país. 
Neste sentido, apesar da cartografia social humana ocupar pouco espaço nas brochuras turísticas portuguesas, é possível observar a representação de um povo exotizado, presente na encenação performativa das baianas, dos indígenas e da capoeira, dispostos em designs que esbanjam cor e movimento, sugerindo um estilo de vida descontraído. De fato, tal como representado nas brochuras turísticas, tais características foram sendo justificadas pelo clima tropical predominante no Brasil e, principalmente, pela miscigenação das raças, tendo como resultado um povo efusivo, exótico e abençoado. Para Leite (2007), as teorias raciais empregadas no país refletiam as doutrinas utilizadas pelos ideólogos do imperialismo, justificando assim o domínio europeu sobre os demais povos: "pior sorte teriam as populações mestiças, tidas como degeneradas porque provenientes da mistura de raças essencialmente diversas" (Schwarcz, 2019, p. 30).

Ainda no que se refere à cartografia social humana, as brochuras portuguesas não demonstram aprofundamento na cultura local brasileira. As representações ligam-se às manifestações culturais estereotipadas, nas quais o visitante assume a posição de mero expectador, mais uma vez reforçando a (re)produção de "não-lugares" (Augé, 1994). Há, portanto, uma artificialização dos atrativos, com perda de identidade, autenticidade e espontaneidade. Como, resultado, tem-se a produção do igual e a criação de um mundo fictício e mistificado de lazer (Yázigi, et al., 1999)

Já as representações das paisagens naturais prevalecem nas brochuras turísticas portuguesas e são marcadas pela exuberância dos atrativos naturais. Os elementos que compõem as imagens desta cartografia reforçam o imaginário de natureza intocada passível de diversas (re)descobertas e maneiras de se desfrutar deste paraíso inalterado. Nela, "estão presentes e visíveis os signos paradisíacos que o leitor dos séculos XVI e XVII compreenderam imediatamente: a referência à abundância e a boa qualidade das águas (...), a temperatura amena (...) e as qualidades da gente (...)" (Chauí, 2010, p. 62). Assim, a partir de um imaginário de fantasia, o conteúdo visual das brochuras turísticas portuguesas parece reproduzir as impressões deixadas pelos primeiros navegantes, o discurso religioso, a literatura de viagens e, mais tarde, a produção intelectual nacional, que não só descreviam o Brasil como um verdadeiro Paraíso Terreal, dotado de riquezas naturais, como destacavam e propagavam as possibilidades de exploração da nova terra. Como observa Paganotti (2009, p. 59), os "mitos fundadores do Brasil e diversos estereótipos sobre a imagem do país como Paraíso Terrestre são repetidos ou readaptados" na construção da imagem do país.

No caso das brochuras turísticas inglesas, no que diz respeito à cartografia cultural urbana, percebe-se que de forma semelhante às brochuras portuguesas, o patrimônio material ali representado é expresso do ponto de vista do colonialismo. De maneira geral, os elementos visuais que compóem a paisagem urbana encenam uma suposta autenticidade colonial. O espaço cultural urbano também revela e intensifica a exoticidade que se deseja apresentar por meio do contato com as comunidades locais. Por outro lado, a cartografia urbana das brochuras turísticas inglesas também é marcada por uma certa familiaridade sugerida pela modernização de seu conjunto arquitetônico. Neste sentido, em uma espécie de fascínio pelo Outro, Guimarães (2006) sugere que o visitante tem buscado não apenas o estranhamento, mas a familiaridade que o mundo oferece, esperando assim, que o exótico e o familiar possam ser solicitados por encomenda.

Em relação à cartografia social humana, as brochuras inglesas destacam as manifestações culturais exotizadas e erotizadas como resultado de uma cultura miscigenada, demonstrando as possibilidades de experiências exóticas. Neste cenário, destaca-se a presença de mulheres com trajes carnavalescos e corpos seminus, a prática da capoeira e os rituais místicos associados à figura das baianas, possibilitando generalizaçóes e simplificações da cultura brasileira.

Vale lembrar que as imagens, desde a sua idealização, não estão livres de intencionalidades, mas se apoiam em um imaginário repleto de expectativas sobre um destino anunciado, bem como sobre um ideal de representação das mulheres. Aqui, a figura feminina nativa não simboliza somente a exotização marcada pela miscigenação racial, mas, sobretudo, demonstra a erotização da mulher brasileira, retratando uma possível liberdade sexual. Em outras palavras, elas "existem primeiro para o olhar do Outro masculino" (Jardim \& Kabelac, 2019, p. 157). 
Somado a isso, o conjunto de cores vibrantes colabora para a associação do comportamento despojado e o estilo de vida livre da sociedade brasileira, reforçando o imaginário distintivo de um povo efusivo, exótico e abençoado. Neste sentido, Brito (2010) chama atenção para o fato que, sob o paradoxo da identidade e alteridade, se erguem os pilares ideológicos do mundo ocidental. Ou melhor, "o nativo é visto como um remanescente de culturas pré-históricas que vivem do mesmo modo através de tempos. Ele é intocado e não tem sido afetado por mudanças" (Guimarães, 2006, p. 114).

Embora a paisagem natural das brochuras turísticas inglesas seja fortemente marcada por um conjunto de referências que apresentam a natureza intocada e selvagem, há dois espaços distintos. O primeiro espaço compõe-se pelo ambiente rico em diversidade natural, que à semelhança da literatura de viagens parece reproduzir não somente as viagens científicas exploratórias em busca de conhecimento sobre o Novo Mundo, distante da civilização, mas sobretudo, o encontro com o Outro primitivo. Assim, as mensagens convidam o visitante a se aventurar em múltiplas possibilidades de descobertas e exploração. Apesar de as imagens de hotéis e resorts serem formas de publicidade disfarçadas, representam aqui o segundo espaço dentro da paisagem natural e servem de proteção contra a alteridade do Outro. Neste caso, trata-se de espaços "turistificados", ou seja, modernas estruturas de lazer em confortáveis meios de hospedagem à disposição para comodidade do visitante.

Nota-se, assim, que de maneira geral, ambos os países, por meio das brochuras turísticas, promovem a representação do Brasil com vista a satisfazer e despertar o interesse de seu potencial visitante. Neste contexto, o país se transforma em uma mercadoria e a criação de um mundo fictício e mistificado de lazer se faz essencial para impulsionar sua venda como destino turístico. Assim, as brochuras turísticas formam um cenário exoticamente convidativo, reforçando e propagando estereótipos e mitos coloniais.

\section{CONSIDERAÇÕES FINAIS}

A imagem do Brasil carrega marcas do passado colonial, realidade que, muito antes da promoção turística, já atravessava a expressão cultural do próprio país. Decerto, as narrativas de viagens de autores estrangeiros, a literatura colonial e a produção textual nacional, encarregaram-se de difundir as teorias de superioridade europeia: "pode-se dizer que a América foi sendo desenhada e descrita por pensadores, artistas, navegadores e autores, durante um longo processo de conhecimento e estabelecimento de identidades" (Bignami, 2002, p. 79). Assim, o estado intocado da natureza, a miscigenação e, consequentemente, a exotização da cultura, atribuíram ao país a condição de atraso e, portanto, dependente da ação civilizadora europeia.

No âmbito da promoção turística, as representações predominantes, muitas vezes, reproduzem formas coloniais de discursos ao referirem-se ao país como verdadeiro paraíso natural, intocado pela civilização moderna, no qual se possa regressar a uma espécie de passado colonial imaginado, com sua cultura exotizada e uma população nativa disposta a atender à todas as necessidades dos visitantes estrangeiros.

Sob a perspectiva metodológica, a análise de conteúdo permitiu acessar as representações simbólicas envolvidas na percepção do Brasil como Outro, no que respeita a mensagem visual. Já a abordagem empregada a partir do recurso da semiótica forneceu a chave de interpretação dos significados e simbolismos gerados pelas mensagens visuais. Foi, assim, possível verificar que a representação do Brasil promovida nas brochuras turísticas em análise refletem um padrão de estereótipos e mitos coloniais acerca do país e de seu povo.

Sendo assim, ao analisar as brochuras turísticas produzidas por Portugal e pela Inglaterra foi possível destacar um conjunto de referências que caracterizam o Brasil a partir de três dimensões: cultural urbana, paisagem natural e uma perspectiva social humana, constituindo-se por cartografias ou paisagens culturais imaginativas de representação do Brasil. Em linhas gerais, a cartografia cultural urbana, relaciona-se diretamente com o patrimônio material/imaterial. Já a paisagem natural refere-se à forma como a natureza é representada, às múltiplas possibilidades de o visitante vivenciar experiências e a estrutura que suporta a 
atividade turística; enquanto a cartografia social humana é baseada na origem, estilo de vida, comportamento e crenças da população brasileira.

$\mathrm{Da}$ análise mais profunda das cartografias e paisagens reveladas pelas brochuras turísticas analisadas, emergiram as categorias gerais de representação do Brasil. Dentro da cartografia cultural urbana, destacouse o passado histórico representado a partir do colonialismo: a "rota do ouro". No que se refere à cartografia social humana evidenciou-se o estilo de vida e o comportamento do povo brasileiro: "a explosão de alegria de suas gentes". Por fim, na paisagem natural evidenciou-se a exaltação da natureza sonhada - "um paraíso junto ao oceano" - e a organização da experiência turística.

As representações expressas nas brochuras turísticas portuguesas e inglesas apresentam similaridades e diferenças. De maneira geral, o passado histórico ligado ao colonialismo perpassou em todo o material analisado. Os elementos que compóem a paisagem urbana encenam uma suposta autenticidade colonial, apresentando um Brasil reduzido do ponto de vista do colonialismo. Ou seja, tudo se passa como se o tempo tivesse cristalizado o patrimônio material, não tendo o país qualquer outra história para além daquela produzida pela colonização. De forma semelhante, a cartografia social humana funcionou como um marcador étnico na construção do Outro exotizado, distintivamente diferente do "eu". Este espaço social é marcado pela exaltação das manifestações miscigenadas, consequentemente, exotizadas - a capoeira, o sincretismo religioso das baianas - da mesma forma como é apresentando o estilo de vida do povo brasileiro - efusivo, exótico e abençoado -. Já as paisagens naturais remetem a ideia de natureza intocada, a antiga crença de Paraíso Terreal, expondo cenários paradisíacos de praias inabitadas, flora e fauna brasileira passíveis de (re)descobertas e desfrutes.

Contudo, tais brochuras turísticas expressam também algumas diferenças do ponto de vista do país que as produziu. Além do olhar colonial lançado sobre o Brasil, as brochuras turísticas inglesas também são marcadas por uma sutil familiaridade sugerida pela modernização presente na representação de um espaço contemporâneo. Assim, é possível instigar o visitante a querer conhecer o Outro exótico e, ao mesmo tempo, gerar segurança ao demonstrar certa familiaridade com seu local de origem. Ademais, enquanto as brochuras turísticas inglesas que compõem a cartografia social humana apresentam o carnaval, com mulheres em trajes carnavalescos e corpos seminus, somando ao exótico a erotização das mulheres brasileiras por meio da sensualização de seus corpos, as brochuras turísticas portuguesas apresentam uma encenação da função imaginativa desempenhada pelos grupos indígenas, reservando ao nativo a posição de exótico adereço cultural. Em relação à paisagem natural, além de imagens de uma natureza inalterada, as brochuras inglesas apresentam modernas estruturas de lazer em meios de hospedagem, o que serve de proteção contra a alteridade do Outro e oferece comodidade e conforto. Dessa forma, criou-se a imagem de um Brasil exótico, mas repleto de espaços familiares e seguros. No caso das brochuras turísticas portuguesas, apesar da forte presença do "eu" colonial, não ocorre um forte apelo à produção do Outro. Ao contrário, a imagem do Brasil encontrou-se fortemente marcada pela produção do igual. Isto é, para os portugueses, o Brasil funciona como uma espécie de extensão do próprio lugar.

No turismo, a exotização dos destinos como forma de torná-los cada vez mais atrativos aos visitantes é essencial. No entanto, promovem uma apresentação, muitas vezes, estereotipada e redutora do potencial total do local e de sua gente, conforme salienta Carvalho et al. (2016, p. 112): "Caso os países não deem a devida atenção, correm o risco de que suas imagens continuarem sendo baseadas em estereótipos e associações desatualizadas ou inapropriadas, gerando consequências negativas no curto e no longo prazo". Vale destacar também que, a reprodução desses discursos, seja com conteúdo textual ou visual, geram implicações não apenas no turismo e na cultura como, também, influenciam nos aspectos sociais, econômicos e políticos de maneira desfavorável, haja vista que a capacidade de captação de recursos e investimentos de um país está diretamente ligada à sua imagem.

Por fim, vale ressaltar que devido ao grande impacto dos acontecimentos ambientais de 2020 sobre a imagem do Brasil no exterior, existe a possibilidade de as representaçóes atuais produzidas e divulgadas 
pelos mercadores de viagens sofrerem alterações. Além disso, a presente pesquisa não teve o propósito de ser conclusiva em relação à imagem do Brasil, mas sim, de apresentar uma realidade passível de intervenção e, dessa forma, servir como recurso complementar na estratégia de reposicionamento da imagem do Brasil. A partir do conhecimento mais aprofundado da imagem do Brasil nos materiais analisados, pode haver um planejamento e direcionamento das campanhas promocionais com o intuito de "desestereotipar" a imagem do país.

\section{REFERÊNCIAS BIBLIOGRÁFICAS}

Agassiz, L. (1868). Journey in Brazil. Houghton Mifflin and Company.

Alvim, P. (2012). Brasil no olhar dos viajantes [Documentário]. Direção: João Carlos Fontoura TV Senado, 60 min.

Augé, M. (1994). Não-lugares: introdução a uma antropologia da supermodernidade. (Tradução Maria Lúcia Pereira). Papirus.

Bardin, L. (1991). Análise de Conteúdo. Edições 70.

Barker, C. (2003). Cultural Studies: Theory and Practice. SAGE Publication. $2^{\mathrm{a}}$ Ed.

Barthes, R. (1982). A retórica da imagem. In O óbvio e o obtuso. (Tradução Isabel Pascoal), edições 70.

Bignami, R. (2002). A imagem do Brasil no turismo: construção, desafios e vantagem competitiva. Aleph.

Brito, F. A. (2010). Identidade e imigração: a representac\#a\#o social do "outro" na televisão espanhola. In Matrizes, 1 , pp. 227-231.

Buckle, H. T. (1857). History of Civilization in England. J. W. Parker and Son.

Campos, C. J. G. (2004). Método de análise de conteúdo: ferramenta para a análise de dados qualitativos no campo da saúde. In Rev Bras Enferm, 57(5), pp. 611-614.

Caton, K. \& Santos, C. A. (2008). Closing the hermeneutic circle? photographic encounters with the other. In Annals of Tourism Research, 35(1), pp.7-26. DOI: http://dx.org.10.016/j.annals.2007.03.014.

Carvalho, D. T. et al., (2016). Experiência em website de marca-país e a formação da imagem de destino turístico: um estudo na Islândia. Revista Brasileira de Pesquisa em Turismo, 10(1), pp. 108-128, jan./abr. DOI:https://doi.o $\mathrm{rg} / 10.7784 /$ rbtur.v10i1.1019

Castro, S. (2008). A Carta de Pêro Vaz de Caminha. L\&M.

Chauí, M. (2010). Brasil: mito fundador e sociedade autoritária. Fundação Perseu Abramo. Chetty, D. (2011). The Exotic "Orient" in Gender and Tourism. In Morady, F. \& Siriner, I. (Eds.). Globalisation, Religion \& Development. I JOPEC Publication.

Cordeiro, M. J. (2010). Olhares alemães: Portugal na literatura turistica - guias de viagem e artigos de imprensa (1980-2006). Universidade Nova de Lisboa, Colibri.

França, J. M. C. \& Raminelli, R. (2009). Andanças pelo Brasil Colonial: catálogo comentado (1503-1808). Editora UNESP.

França, J. M. C. (2012). A construção do Brasil na literatura de viagem dos séculos XVI, XVII e XVIII: antologia de textos (1591-1808). Rio de Janeiro: José Olympio; São Paulo: Editora UNESP.

Guimarães, V. M. (2006). A modernidade e os encontros turísticos: turistas na Barra da Lagoa. Tese de Doutoramento Interdisciplinar em Cie\#ncias Humanas. Universidade Federal de Santa Catarina, Centro de Filosofia e Cie\#ncias Humanas.

Hassan, H. (2014). The representation of Malaysian cultures in tourism brochures. In Procedia-Social and Behavioral Sciences, 118, pp.140-151. DOI: http://dx.org/10.1016/j.sbspro.2014.02.019.

Hue, S. M. (2013). This voyage is good as any Peru voyage. The Minion of London in Brazil (1581). História (Sa\#o Paulo),32(1), pp. 31-52. 
Jardim, G. S. \& Kabelac, B. C. (2019). Mulheres, Automóveis e Destinos Turísticos no Brasil: uma análise sobre algumas representações do feminino na publicidade da Revista Quatro Rodas. Revista Turismo em Análise,30(1), pp. 151-183. DOI: http://dx.doi.org/10.11606/issn.1984-4867.v30ilp151-18

Knauss, P. (2012). Brasil no olhar dos viajantes [Documentário]. Direção: João Carlos Fontoura TV Senado, 60 min.

Lima, P. S. F. \& Palacios, A. R. J. (2019). Breves considerações sobre processos de apropriação de traços identitários brasileiros, em anúncios publicitários do Instituto Brasileiro de Turismo-Embratur. Revista Turismo em análise,3(1), pp. 131-150. DOI: http://dx.doi.org/10.11606/issn.1984-4867.v30i1p131-150.

Leite, D. M. (2007). O caráter nacional brasileiro: história de uma ideologia. Editora UNESP (Colec\#a\#o Dante Moreira Leite).

Melo, E. C. (2012). Brasil no olhar dos viajantes [Documentário]. Direção: João Carlos Fontoura TV Senado, 60 min.

Paganotti, I. (2009). Imagens do Brasil turístico nas páginas do New York Times. Revista Pensamento \& Realidade,24(2).

Palazzo, C. L (2012). Brasil no olhar dos viajantes [Documentário]. Direção: João Carlos Fontoura TV Senado, 60 min.

Pereira, P. R. (1999). Os três únicos testemunhos do Descobrimento do Brasil. Lacerda Editores.

Romero, A. G. (2016). No país dos ventos alísios: leituras sobre Henry Thomas Buckle no Brasil republicano. Revista Vernáculo, $2,2^{\circ} \mathrm{sem}$.

Schwarcz L. M. (1993). O espetáculo das raças: cientistas, instituiçóes e questo\#es racial no Brasil - 1870-1930. Companhia das Letras.

Schwarcz L.M. (2019). Sobre o autoritarismo brasileiro. Companhia das letras

Seixas, M. L. B. (2003). A natureza Brasileira nas fontes portuguesas do século XVI. Para uma tipologia das grandezas do Brasil. Passagem.

Sodré, N. W. (1965). A ideologia do colonialismo. Civilização Brasileira.

Teixeira, F. M. P. (2000). História concisa do Brasil. Global.

Vainfas, R. (2012). Brasil no olhar dos viajantes [Documentário]. Direção: João Carlos Fontoura TV Senado, 60 min. Yázigi, E., Carlos, A., Cássia, R. \& Cruz, A. (1999). Turismo: Espaço, Paisagem e Cultura. Editora Hucitec. 